\title{
Disfiguring Socratic Irony
}

\author{
Eric Detweiler
}

\section{A B S T R ACT}

This article pursues an antihermeneutic conception of Socratic irony that troubles the borders between pedagogical authority and humility. One of the most tenacious ways of troping the teacher-student relation, Socratic irony is often figured as a way for a masterful teacher to exercise authority over a student. Drawing on the writings of Søren Kierkegaard and Avital Ronell, this article repositions such irony as an uncontrollability in language itself - one that can humble and humiliate teacher and student alike. Via divergent readings of Plato's Gorgias and Aristophanes' Clouds, as well as Bruno Latour's interpretation of the former, I question how this approach to Socratic irony might re- and unwork rhetoricians' positions of mastery with regard to both students and systematized bodies of knowledge.

KEYWORDS: irony, Socratic irony, pedagogy, rhetorical theory, Continental philosophy

\section{INTRODUCTION}

Let us count, rather, on disarray.

-Maurice Blanchot, The Writing of the Disaster

Perhaps "since the beginning of time" is an inauspicious way to begin a composition. And yet, given the project I am undertaking, it does not seem too far off. Let us say this: from the very start of the pedagogical tradition associated with Western rhetoric, which is often represented as having its roots in ancient Greece, the figure of the rhetoric teacher has had a remarkably fraught relationship with cultural and political authority. Just 
consider the double legacy of Socrates as both-on one hand-the West's original wise man, a revered and beloved pedagogue, and —on the other-a bothersome wise guy and disruptive corrupter of youth. ${ }^{1}$ In Aristophanes' Clouds, which positions Socrates as a sophist rather than a philosopher, he even comes across as a bit of a huckster. Or consider Against the Sophists, in which Isocrates argues that "sophists" are driven by a "desire for ... profit" and have a deservedly "bad reputation among the general public" even as he advertises his own program of rhetorical education (2000, 6I-62). Later in his career, Isocrates positions himself as a man of humble means (Antidosis I55), an adjunct of the "leisured" class whose students left his care "with regret and tears" $(213,22 \mathrm{I})$.

These tensions between humility and authority, between masterful wisdom and pretentious chicanery, were also commonplace during classical Rome's Second Sophistic. Even as rhetorical education received a degree of imperial recognition and sanction, "the rhetorician's school" remained "a small, and in many cases precarious, business" (Walker 20II, 4). Libanius, "who held the municipal chair of rhetoric in Antioch" (20II, I6I), conceives of the rhetorician as a second father to his students, with "a student's dependence on and closeness to his teacher ... produc[ing] mutual feelings of affection" (Cribiore 2007, 139). At the same time, however, he complains of inadequate funding as well as disrespectful students who despise their instructors and threaten to take their parents' money elsewhere at the first hint of disciplinary action (Walker 20II, I6I). ${ }^{2}$

In short, rhetoric teachers were both revered and reviled, positioned as authoritative yet humble masters as well as effete deceivers with their heads in the clouds and hands in their students' purses. Their authority as surrogate father figures was transient and constantly destabilized by parents, parodists, pupils-even by fellow teachers with whom they competed for students and funds. Raffaella Cribiore (200I) notes that "accusing someone of being a schoolteacher, or of having a schoolteacher as a father, was a common insult" (59). For ancient and classical teachers, the challenge was to restabilize their authority by situating themselves as adjuncts to but not members of the leisured class, leveling invective at their competitors while winning both the devotion of students and support of political and cultural authorities.

In subtly similar ways, contemporary teachers of rhetoric and writing also experience these tensions: for every movie about an adept writing teacher who inspires a class of students to change themselves and the world, there is a comedy featuring an absent-minded professor who can barely 
manage a piece of chalk. And while colleges and universities afford some teachers a much greater degree of professional stability than the precarious businesses of their classical forerunners, the increasing adjunctification of higher education in general and rhetoric and writing in particular leaves many teachers in a distinctly marginal position (Crowley I998, II8).

But while the outrageous financial situations faced by adjunct and contingent teachers are surprisingly similar to those faced by Libanius's contemporaries, the antinomies of pedagogical authority resonate quite differently for many present-day teachers of rhetoric than they did for classical predecessors. Many of today's teachers hold ethical concerns about authority relations between teachers, students, and broader institutions and structures that did not trouble ancient teachers. Consider Sharon Crowley's warning that "classical rhetorical theory was devised a long time ago in cultures that were rigidly classbound" and "invented for the use of privileged men" $(1998,264)$. If the struggle for classical teachers was stabilizing an ethos of pedagogical authority reliant on and defined by rigidly patriarchal and class-bound (if occasionally democratic) systems-systems in which the goal was to turn out students prepared to inhabit and/or protect similarly rigid systems - then what are rhetoricians suspicious of such systems to do? How are we to negotiate our own authority if we wish to resist a model of education designed to "produce a professional managerial class schooled in the art of obedience to authority and accepting of dominator-based hierarchy" (hooks 2003, 20)? Put otherwise, how might we teach our student bodies - no longer just male, no longer constituting a homogeneous cultural, ideological, or socioeconomic milieu-to question structural authority without abdicating our own pedagogical authority or participating in the denigration of teachers as ethically and intellectually suspect, as parasites (a denigration that persists in overwrought attacks on "radical" humanities professors, as well as much of the discourse surrounding education reform and the defunding of public education)?

In this article, I explore these questions by going back to the start, taking up a tricky trope (or perhaps not a trope) that has haunted the Western pedagogical tradition since its inception: Socratic irony. I argue that this trope, which troubles the borders of authority and humility, wisdom and stupidity, constitutes a fertile topos from which to trace out ethically and intellectually responsible approaches to pedagogical and rhetorical "authority." Rather than going right to Socratic irony, however, let me spend a moment dwelling with irony more generally, a "trope" that has-historically, practically, and conceptually - troubled quite a few borders of its own. 
I will recall this stopover with irony as I go on to examine iterations of Socrates in the works of various rhetoricians, philosophers, and theorists. From there, I will tease out a lengthy consideration of Plato's Gorgias, questioning the rhetorical and figural stability of that text's Socrates. Then I will turn to Bruno Latour's reading of the Gorgias, chase that with a look at Aristophanes' Clouds, and subsequently argue that these texts serve to befog further both Socrates' fractured figurations and the irony that those figurations so frequently claim does not characterize Socratic discourse. I end with some inconclusive conclusions that hitch these conceptual and figural concerns to the pedagogical situations faced by contemporary rhetoricians.

\section{IRONY: A BRIEF WORD}

What is irony? A stupid question if ever there was one, but perhaps my inescapable starting point. It is, after all, what one might call a Platonic question, and Socratic irony of course owes much of its historical legacy to Plato. ${ }^{3}$ I position this question as "Platonic" insofar as it presumes that "irony" has some essence characterized by fixed, generalizable qualities toward which one can gesture. Tying irony to constative meanings and fixed qualities entails certain difficulties, however (de Man 1996, I64). In many ways, it is easier to describe what irony does than it is to say what irony is. It is easier, in other words, to speak about it in performative terms, which leads to an odd paradox: if irony is anything, it is what it does- that is, it "is" performative- and so maybe does not have any substantial, substantive identity at all. ${ }^{4}$ As Avital Ronell observes, nothing puts one at risk of ironic effacement like trying to exert ironic authority or pronounce authoritatively on irony (2002, 128-29). In "The Rhetoric of Testing," a chapter in a book called Stupidity, Ronell writes,

Often the decisive interventions on the part of irony bear effects of physicality; they give a sound beating to a language that closes in on itself. ... Like Socrates, it functions as gadfly, as an internal allergen that appears to come from a place of exteriority, undoing all transcendental systems, constantly rewriting the text that it submits to endless retests, retaking acknowledged premises on a permanent basis. This is why irony is no joke. $(2002,156)$

In what follows, then, I resist Platonic attempts to define "irony" and "Socratic irony" and instead follow in the footsteps of those who have 
approached irony more haltingly, more attentive to its predilection to make you play the fool-though surely I will fall down on the job at least once or twice. In all, I position "what is irony?" as a Platonic question that is impossible to answer definitively and-recalling Ronell-set up the rest of this article as "antihermeneutic." Ronell ends "The Rhetoric of Testing" with what must be one of the twenty-first century's most open-ended "tests," one constituted by such items as "What is the relationship between stupidity and unintelligibility?" and "Show how Friedrich Schlegel's antihermeneutics of friendship illuminates what Blanchot and Derrida have to say about the politics of friendship" (2002, 162, emphasis mine). These test questions in some ways frame the (perhaps stupid) task I am undertaking and undergoing here. This task might be glossed as a tracing of the relationship between pedagogy and irony, as well as irony's antihermeneutic implications for the politics of pedagogical relations. ${ }^{5}$ While hermeneutic approaches to Socratic pedagogy and irony might aim for "understanding" and interpretations grounded in stabilized meanings and authorial intentions, I position my approach as "antihermeneutic" because I set out expecting the unexpected: that the borders of concepts, theories, practices, and disciplines will blur in curious ways (although I do not assume that my expectations will guarantee any meaningful transcendence or ironic refixing of such borders). ${ }^{6}$ Contrast this project, if you will, with Iakovos Vasiliou's (2002) "Socrates' Reverse Irony." Via sharp readings of Plato's Apology and Gorgias, Vasiliou pinpoints a "trope" he calls "reverse irony" and concludes that "recognizing reverse irony is important for understanding Socrates' method.... [It] is ... an expedient and efficient means of generating perplexity" (230). Meanwhile I, via a dull reading of the Gorgias and a handful of other texts, am stuck on what happens when neither the interlocutor, nor the reader, nor the Socratic figure "walk away ... from a Socratic discussion believing that he [isn't it always?] has the sort of expert knowledge of a virtue that would reliably enable him to pick out instances of that virtue" (225). I set out expecting to get buffeted and buffaloed by irony "constructed as the rhetorical test site par excellence" (Ronell 2002, I2I), poised to fall into yet another trope that Vasiliou names early on: "that most Socratic of all results: aporia" (22I).

\section{FIGURES OF SOCRATES}

I try to hold open the preceding questions about "irony" as I consider the proceeding questions: What is Socratic irony, and (how) can one think about 
it while avoiding or working around precisely that Platonic question? Does the Socratic pedagogue use or get used by irony? Given the "effects of physicality" that Ronell attributes to irony, is a Socratic irony that does not do violence to students, teachers, and their languages desirable and/or possible? And, all told, might such questions lead us to rethink the authority relations between students, teachers, language systems, and knowledge? None of these, I do not think, are yes-or-no questions.

In contemporary parlance, however, what is often glossed as "Socratic irony" or the "Socratic method" depends almost entirely on yes-or-no questions, or at least on questions enclosed within systems that programmatically delimit what counts as a "right" or "wrong" answer: Platonic idealism, the American legal code-even standardized tests might fit the bill here (see Latour 1997, 224). ${ }^{7}$ Whether the goal is Truth, a law degree, or a high GRE score, the deep unpleasantness of such systems-from the unenviable rhetorical position of Plato's Socrates' yes men to modern students tossing and turning the night before a big multiple-choice test-is unquestionable. Within these systems' more traditional iterations, the author (e.g., Plato) or other authority figure (e.g., the College Board) has presumably mastered the system's contents and method, and any apparent lack of knowledge on the part of that masterful, authoritative figure is pure dissemblance. This is a further limiting of the conception of "the Socratic" offered by Yun Lee Too: the erotic teacher, she argues-Socrates being in her estimation one such teacher-is "one who temporarily stages the scene of intellectual resourcelessness, whether actual or feigned, ... such that lack of knowledge remains specific to the pedagogical scenario and stands apart from any actual inadequacy that the student may feel" $(2000,76)$. Contra Too, contemporary conceptions and deployments of "Socratic irony" both position the master's staging of "intellectual resourcelessness" as always "feigned" and-whether purposefully or accidentally — seem to excel at feeding students' feelings of anxious "inadequacy."

Such discursive systems may claim to proceed in a "Socratic" manner, but a number of their critics have positioned Plato as their progenitor. Michel Foucault puts it like this: "In every society the production of discourse is at once controlled, selected, organized, and redistributed according to a certain number of procedures, whose role is to avert its powers and its dangers, to cope with chance events, to evade its ponderous, awesome materiality" $(1982,217) .{ }^{8}$ Foucault then elaborates on three such "procedures": prohibited speech, the division of reason and folly (which I bracket here, though folly and irony often run in the same circles), and the opposition 
between "true" and "false" discourse (2I8). He is particularly interested in the latter, which he blames on Plato. Foucault claims that Plato's exclusion of the sophists instantiated the true/false opposition by relegating discourse to its "said" form and attempting to sunder all links to the allure of its "saying." Foucault's powerful, desirous "saying” resonates with Gorgias's "Encomium of Helen." In the encomium-which Gorgias describes as a "paignion" (amusement or plaything) that aims to "free the accused [i.e., Helen] from blame" (Gorgias 2007, 256, 252) — the famous sophist describes "speech" as "a powerful lord that with the smallest and most invisible body accomplishes most godlike works" (253).

Foucault might thus point to Plato's Gorgias as a key moment in the incarceration of the sophists and sophistic sayings. Near the start of the dialogue (449c), Plato's Socrates requests that Gorgias stick to "the short style of speech, and leave the long style for some other time" (Plato 1987, 5). Plato's Gorgias obliges, at least initially, replying with the one-word yes-orno answers so typical of Plato's Socrates' interlocutors.

Given that I am on the trail of Socratic irony, however, let me note two complications before I play around with the Gorgias in the "long style." First, despite Plato's singular influence on contemporary perceptions of Socrates, we have at least two other accounts that confound his portrait: Xenophon's and Aristophanes'. Søren Kierkegaard elaborates on and compares these views at the start of The Concept of Irony. Despite confessing a "perhaps somewhat youthful infatuation with Plato" (1989, 25), Kierkegaard is not entirely dismissive of Xenophon, "a second-rate fellow were it not for the chinks in his presentation" (27). These presentational gaps have to do with Plato's and Xenophon's respective approaches to irony, which Kierkegaard touches on in a footnote: "The ironic in Xenophon is never the floating of irony blissfully resting in itself but is a means of education, therefore at times encouraging to those from whom Socrates is actually expecting something" (25). For Kierkegaard, the "education" provided by the Socrates of Xenophon's dialogues is a "utilitarian" reinscription of Greek cultural commonplaces. Meanwhile Plato, Kierkegaard's dreamy crush, uses Socratic irony to transcend such commonness.

But even the infatuated Kierkegaard does not give Plato the last word on irony, turning from Xenophon to Plato to the comic playwright Aristophanes. He positions the Socrates of Aristophanes' Clouds as “just the necessary contrast to Plato's. ... Indeed, it would be a great lack if we did not have the Aristophanic appraisal of Socrates; for just as every parody is an assurance that this process has outlived its day, so the comic view 
is an element, in many ways a perpetually corrective element, in making a personality or an enterprise completely intelligible" (I28). The notion of rendering something "completely intelligible" might seem inimical to my proclaimed antihermeneutic approach to irony. After all, Ronell, reading Schlegel, associates irony with unintelligibility (2002, I46). That Kierkegaard positions the "comic view" as a "perpetually corrective element," however, suggests that for Kierkegaard, "complete" intelligibility is always a work in progress. The Concept's next sentence frustrates intelligibility even further: "Even though we lack direct evidence about Socrates, even though we lack an altogether reliable view of him, we do have in recompense all the various nuances of misunderstanding, and in my opinion this is our best asset with a personality such as Socrates" (128, emphasis mine). If Kierkegaard is claiming Aristophanes makes Socrates "completely intelligible," then, it is only insofar as the playwright rounds out a gallery of misunderstandings, adding another shady character to a lineup of unusual subjects. For Kierkegaard, laying Plato's, Xenophon's, and Aristophanes' characterizations beside or on top of each other reveals not a full picture of Socrates but "the cryptic nothing that actually constitutes the point in Socrates' life" (153), a lack that constitutes Socrates' core.

This view resonates with Ronell's take on irony, but runs contrary to those who would either (a) valorize Socrates as the progenitor or mouthpiece of earnest Platonic doctrines, or (b) critique Socrates as a figure who uses irony as a mode of straightforward dissemblance, as a duplicitous trap deployed to flip the script on relativistic wise guys. ${ }^{9}$ This brings me back to the second complication I promised a few paragraphs ago: Plato's Socrates is already fragmented. This is well established in the traditional subdividing of Plato's dialogues into early, middle, and late. As Donald J. Zeyl notes, "The Gorgias is generally considered the be one of the last of Plato's early dialogues and so is often thought to represent the views, methods, and personality of the historical Socrates" (I987, xii). In what follows, I give this screw one more turn, claiming that even within the discrete text called the Gorgias, interlocutors and readers encounter a patchwork Socrates written by a multivalent Plato who shifts views and methods in a manner that troubles not only a unified conception of "the Socratic" but the border between "Socratic" and "sophistic." While many scholars in philosophy and rhetoric position "the quarrel between Gorgias and Plato" as presaging modern debates about the relative intellectual merits of rhetoric and philosophy (Hauser 2004, 40), I explore this "quarrel" as a way to-perhaps ironically_question the lines not only between "Socratic" and "sophistic," 
but also between such other pairs as philosophy and rhetoric, student and teacher, and eiron and alazon. ${ }^{10}$ So let us fall into the "cryptic nothing" of the Gorgias, probing some potentially unintelligible moments in the text.

\section{SOME VIEWS MADE (IM)POSSIBLE: INTERRUPTING THE GORGIAS}

In the Gorgias, Socrates debates the nature, qualities, and political merits of rhetoric with three primary interlocutors. First up is the sophist and orator Gorgias, who has just finished giving "an admirable, varied presentation” (Plato 1987, I). Gorgias is followed by two of his admirers: Polus and Callicles. Some readers of the dialogue-Bruno Latour, for instancedescribe Socrates as "defeat[ing]" these interlocutors "one after the other: Gorgias, a bit tired from the lecture he has just given; Polus, a bit slow; and finally the harshest of the three, the famous and infamous Callicles" (I997, I92). I will return to Latour's reading, but for now pause only to note that "defeat" may be too strong a word. Zeyl, for instance, claims that "Polus is reduced to silence (but not to consent) and retires from the discussion" (I987, xiii, emphasis mine). It is also worth noting that Polus seems to enter the dialogue by interrupting, jumping in before Gorgias can reply to one of Socrates' rejoinders and doing so with a frustrated, flustered, and syntactically fractured utterance that begins, "Really, Socrates?" (3I). It thus seems questionable whether Gorgias is overcome by an antagonist or pushed aside by a would-be ally.

Until Polus's interjection, in fact, Gorgias seems comfortable playing along with Socrates, the only one of the interlocutors who seems to take any delight in the proceedings (449c; 505c). Though Socrates later enjoins Callicles not to "jest" "paizein") (77), Gorgias-who, as we have seen in the "Encomium of Helen," has a fondness for playthings (Gorgias 1987, 256) seems to approach the affair with significantly less exasperation than his followers. Again, then: that Gorgias is "defeated" seems questionable.

Callicles, like Polus and unlike Gorgias, enters the conversation with an expression of disbelief (48Ib). After Socrates claims that suffering injustice is better than doing it, Callicles turns to Socrates' friend Chaerephon and asks, "Is Socrates in earnest about this or is he joking [paizei]?" (5I). Callicles repeats the question to Socrates himself, who does not offer a direct answer. It is not until a bit later in their conversation that Socrates directly denies that he is dissembling ( $489 \mathrm{~d}-\mathrm{e})$. After he asks Callicles to "go easier on me in your teaching, so that I won't quit your school" (6I), 
Callicles replies, "You're being ironic [eirōneuēi], Socrates" (6r). ${ }^{11}$ Socrates dismisses the charge and turns it back on Callicles: "No I'm not, Callicles, by Zethus-the character you were invoking in being ironic with me so often just now!" (6I).

Whether Socrates' inversion of Callicles' accusation is itself ironic, however, remains unclear. After all, despite his claim to earnestness, Socrates seems subtly playful if not utterly stupid when it comes to following the rhetorical rules he himself establishes for the dialogue. Take his request that Gorgias stick to "the short style of speech [braxulogias], and leave the long style [makrologias] for some other time" (5). Gorgias, adaptable sophist that he is, consents and delivers. Socrates, however, violates his own precepts and speaks at greater length than any of his interlocutors. He is not entirely unaware of this twist, offering Polus the following justification:

Perhaps I've done an absurd thing: I wouldn't let you make long speeches, and here I've just composed a lengthy one myself. I deserve to be forgiven, though, for when I made my statements short you didn't understand and didn't know how to deal with the answers I gave you, but you needed a narration. So if I don't know how to deal with your answers either, you must spin out a speech, too. But if I do, just let me deal with them. That's only fair. (26)

In addition to troubling the limits of his self-imposed stylistic restrictions, Socrates is also slippery about what constitutes an admissible proof. Still speaking with Polus, Socrates says, "Whereas everyone but me agrees with you, you are all I need, although you're just a party of one, for your agreement and testimony. It's you alone whom I call on for a vote; the others I disregard" (42, emphasis mine). Just before he makes this claim, however, Socrates pursues a different line of argument by asking, "Now didn't the majority [pollos] of mankind [anthropos], and you earlier, agree with us that doing what's unjust is more shameful than suffering it?" (4I). Polus concurs, giving Socrates the assent of the only one that the gadfly claims to care about, but Socrates' subsequent claim that he "disregard[s]" the "others" ("alius") is already undercut by this apparent appeal to a great deal of "others" - "the majority" - that precedes his rejection of such appeals' legitimacy. Perhaps this is a playful demonstration that he can, by appealing to the pollós, beat Polus at his own game- that the "philosopher" is in fact better than the rhetor and/or sophist at winning over both the one and the many. If it is such a demonstration, however, it only contributes to 
the ironic undecidability of the dialogue, opening the question of whether we can trust Socrates' claims to earnestness in a dialogue in which he is ironically granted precisely the persuasive powers he projects onto the rhetor (cf. 455a). Perhaps we could work around this problem by reading the appeal to the pollos of anthropos as an appeal to human nature (rather than majority opinion), which Plato's Socrates thus does not see as conflicting with the suspicion he expresses toward the demos during his exchange with Callicles (48Id). At the very least, however, this would then seem to validate Callicles' claim that Socrates is "slyly" manipulating the distinction between "terms of nature" ("physis") and "terms of law" ("nomos") for his own benefit (483a), again throwing into question Socrates' status as eiron and/or alazon. Who knows?

I am posing the question "Who knows?" not as a rhetorical questionat least in the usual sense of "rhetorical question." I ask it not to foreclose response but in order to explore some compossible responses. More specifically, the question is this: in the case of the Gorgias, who knows if and/or when Socrates is dissembling, ironically breaking his own rhetorical rules (on style, arrangement, invention-we could blast away with all five canons of rhetoric and more), and how do the fuzzy boundaries of that "who" delimit the dialogue's rhetorical-pedagogical significance? Furthermore, how might this question complicate our sense of who is reading and who is getting read, who is teaching and who is learning, who is the sophist and who is the philosopher, who is the eiron and who is the alazon, over the course of the dialogue? Some possibilities:

I. One could take the fairly traditional view that Plato knows and that he means for his Socrates to know as well. In other words, the author and his speaker are unified in understanding when and whether they're being ironic. We could take this to mean that a wise and wily Plato is deploying a similarly clever Socrates to outfox the sophists and thus prove philosophy's essential superiority. This would mean Callicles does not get it — that he asks whether Socrates is being ironic due to a sincere lack of understanding. In this case, it could even be Socrates' very sincerity that renders him the ironic master and Callicles the unwitting student: having "abandoned any hope of educating his listeners," he utilizes a "reverse irony," speaking sincerely in the understanding that those hapless listeners will be unable to hear his earnest views as anything other than ironic (Vasiliou 2002, 226). In such a reading, Socrates becomes either the 
eiron whose mastery never slips or the alazon whose simple wisdom topples Callicles, the pretentious eiron.

2. Perhaps Plato, Socrates, and the interlocutors are in on it: Plato and his Socrates are playing a game with rather than at the expense of Callicles, Polus, and Gorgias. In this case, we can perhaps take the dialogue as one of the written "amusements" Plato's Socrates describes in the Phaedrus (1995, 82). Socrates is jesting with Callicles when he asks him not to jest, Callicles is just jesting back, Gorgias is having a good time in the margins rather than growing incensed at the philosopher's insults (e.g., 462a), and so on. Such a reading might resonate not only with the Phaedrus, which is typically classified as one of Plato's middle dialogues, but also with George Kennedy's claim that in the "early dialogues" both Plato and his Socrates were, like Gorgias, "probably content to encourage debate and suspend final judgment" (1994, 20). It would also mesh with Plato's Seventh Letter, in which the writer claims that of the "truth" of the matters with which he concerns himself "no treatise by me concerning it exists or ever will exist" (1973, 136). ${ }^{12}$ We could shuffle the deck here a bit, presuming Gorgias is amused while Callicles and Polus are bemused (see Callicles at 505c and 52Ib), or that Polus alone is left out in the cold.

3. Perhaps Plato gets it but means to situate everyone on the "inside" of the dialogue, Socrates included, as alazons. Imagine that Plato, like the writer of a sitcom episode, sets his characters off into a web of scrambled messages and miscommunications, with the supernatural "account" ("logos") at the dialogue's end intended not as metaphysical Truth, but as a means of rebuilding camaraderie in the wake of so many flared tempers (523a). In this case, the dialogue's "lesson" might be similar to one that concludes another of Plato's early dialogues: at the end of the Lysis, the characters' failed attempt to find a stable and coherent philosophy of friendship is precisely what turns them into bosom buddies (223 b).

4. Moreover, one could switch pop-culture idioms and build on Ronell's description of Plato's MO: "Like the survivor of so many police films, Plato was set off by the murder of his partner" (2012, 9). Imagine Plato, after so many years on the beat, retired from his job policing the borders of the political, rhetorical, and philosophical. Finally understanding that - in the end - there is nothing to understand, he turns to writing dialogues that prefigure film noir scripts. 
In this case, perhaps it is Plato's Callicles who gets it; in this reading, Callicles' ominous, pragmatic warnings to Socrates-that clueless idealist - have the same function as the last line of Chinatown (1999): "Forget it, Socrates. It is the agora" (see the allusions to Socrates' trial at 52Ic). Plato's posthumous lesson: give up trying to track down transcendent truth-just look where that got my partner. No eirons or alazons here-just us nihilists.

5. Additionally, one could invert the previous option, questioning intentionality by positioning Socrates as the eiron and Plato as the clueless alazon who never gets it. Imagine Socrates, in other words, shouting some lesson from the pages that the writer is somehow missing. Plato, following Socrates around and frantically marking down the teacher's words, misses the point or lack thereof. He is, like one of Kafka's versions of Abraham, "the class dummkopf ... too dumb to know that he cannot be the smart one beckoned forth on this day" (Ronell 2002, 292). Perhaps the "smart one" is Aristophanes, about whom more in a bit, and perhaps he is the smart one because (option 5b) he realizes that Plato and Socrates are both hot-air buffoons.

6. Finally, though not exhaustively, we could question whether the reader is supposed to get it, whether the dialogue has any didactic or dialectical end. Reiterating Socrates' comments on writing in the Phaedrus, we could question whether Plato intends-though here we would again hit the limits of intentionality - for his writings to communicate anything to anyone else, or whether he is just "storing up reminders for himself 'when he reaches forgetful old age"' (I995, 82). Is there any intended lesson for the Gorgias's recipients, or is it just a cryptic entry in Plato's diary?

Who knows? Who ironizes and who's ironized? Who's learned and who learns? These myriad troubled interpretations also trouble such categorizations: every party involved "could swing on either side of the boundary," not only via oscillations over time but via simultaneous doublings-a laughing at oneself that could be clever and/or stupid (Ronell 2002, 298).

\section{AN ADDITIONAL IMPOSSIBILITY}

The possibilities I just suggested-their proliferation gesturing toward the relative impossibility of ascribing one fixed meaning to the Gorgias-may 
seem too playful. Not only might I have ignored or misunderstood Socrates' request that his interlocutors refrain from jesting (50ob), but perhaps I need to remind myself of Ronell's (2002) claim that "irony is no joke" (156). Or perhaps playfulness is a way to resist slipping into flippancy. Perhaps I might otherwise end up like the "family of theoreticians" Derrida (I988) takes and sends up in Limited Inc:

The more they seek to produce serious utterances, the less they can be taken seriously. It is up to them whether they will take advantage of this opportunity to transform infelicity into delight [jouissance]. For example, by proclaiming: everything that we have said-written-done up to now was not really serious or strict; it was all a joke: sarcastic, even a bit ironic, parasitical, metaphorical, citational, cryptic, fictional, literary, insincere, etc. ( 72 , translator's brackets)

To expand on and test the limits of this playfulness, let us bounce it off the serious concerns Bruno Latour (1997) raises in his reading of the Gorgias: "Socrates' and Callicles' Settlement; or, The Invention of the Impossible Body Politic." ${ }^{13}$ For Latour, all the figures in and around the Gorgias are in on this "settlement," the consequences of which are no joke for the demos. In his reading, the differences between Socrates and "the straw Callicles"-whom Latour opposes to "the positive, or the historical, or the anthropological Callicles" (194)—only disguise a broader agreement: "the simple fact that they all wish to stand alone against the people" (I98). Socrates and Callicles' shadowboxing diverts attention from "a second fight going on silently, offstage, pitting the people of Athens, the ten thousand fools, against Socrates and Callicles, allied buddies, agreeing on everything and differing only about the swiftest means to silence the crowd" (208). Rather than displacing straw Callicles' claim that it is only natural for "the better man and the more capable man to have a greater share than the worse man and the less capable man" (Plato 1987, 54), Latour sees the dialogue's proceedings as recruiting "Force," "Reason," "Morality," "Knowledge," and "Power" in the service of Plato's united Socrates and Callicles and thus against the demos: "Professor Socrates writes on the blackboard his triumphant equation: Politics plus absolute morality minus practical means equals the Impossible Body Politic” (23I). In Latour's reading, Plato's Socrates' equation is a "political weapon" and "war cry" deployed to issue this command: "Keep your mouth shut!” (233). Latour forwards an alternative model 
of deliberation that, though primarily focused on scientific argument, he positions as also relevant to the sorts of social and political controversies addressed in the Gorgias. It is a discussion-dependent model he aligns with extending access, "through experiments and calculations, to entities that do not at first have the same characters as humans" (233).

Latour sees his alternative as "the best and fastest way to free science from politics" and ironically argues that it finds its "clearest" definition in the Gorgias. Who offers this definition? According to Latour, it is "Socratesand here I want to ... make amends for having ironized so much at the expense of this master of irony" (235). Latour quotes the following lines from the Socrates of Plato's Gorgias: "In fact, Callicles, the experts' opinion is that co-operation, love, order, discipline, and justice bind heaven and earth, gods and men. That's why they call the universe an ordered whole, my friend, rather than a disorderly mess or an unruly shambles [kai to olon touto dia tauta kosmon kalousin, ô etaire, ouk akosmian oude akolasian]" (quoted in Latour 235, emphasis and brackets his). ${ }^{14}$

Latour uses this quote to spin out a valorous agenda for scientific and social deliberation, "the task being to turn this collective [i.e., both humans and nonhuman 'entities'] into a 'cosmos' instead of an 'unruly shambles"' (234). This task, Latour argues, refuses the pernicious "acceleration” of scientific dogmatism and antidemocratic Platonism: "It has now been shown that instead of simply adding order," such acceleration "adds disorder as well" (238). He draws a link between his decelerated style of deliberation and "the conditions of felicity for the slow creation of a consensus in the harsh conditions of the agora" (237), conditions that he hopes will allow controversies to be repositioned as "between 'unruly shambles' and 'cosmos"' rather than between "descendants of Socrates" and "descendants of Callicles" (238). ${ }^{15}$

But, as someone who is constantly undone by the "tropologically insecure nature of irony" (Ronell 2002, I2I), let me offer a messy defense of the "unruly shambles." The agora may be preferable to the exclusive violence of a politics powered by tyrannical capitals: Force, Reason, Knowledge, etc. Nevertheless, the agora was quite adept at instituting exclusions of its own: women, slaves, non-Greeks, and gadflies all fared pretty poorly in its "harsh conditions." Though I find much to admire about the dissemination of access that Latour advances, I hesitate when he links it to an "ordered whole." In pursuit of such a totality, Latour claims, "no shortcuts are possible, no short-circuits, and no acceleration." His pursuit of "order" proceeds slowly and carefully, then, but remains tied to a certain set of ends that seem to resonate too readily with-were we to read the Gorgias in/as 
earnest-Socrates' obsession with all things "orderly" (see 454c, 493c, 506d). I wonder whether one might instead linger and wander among the shambles, perhaps accounting for the inevitability of a different class of "shortcircuits" (of understanding, of reason, of order itself) that so often lead to reactionary violence against those slapped with the label of "disorder"those shambling along too slowly to keep up with even the decelerated pace of the agora. I would ask, in short, how we might resist simply replacing Platonic tyranny with yet another (albeit slower) pursuit of order, how we might skid along behind the agora and its related institutions, perhaps picking up and dwelling with those others who have been deemed witless alazons, unwitting eirons, imprudent students, or cretinous teachers- those who cannot, or prefer not to, or do not know how to keep up. It is in the detritus of orderly systems that we might catch up with the victims and followers of irony's disorderly conduct.

\section{BURNING DOWN THE HOUSE}

There is irony and there is something else.

-Jacques Derrida, "Remarks"

Let me follow Kierkegaard in letting Aristophanes come after and complicate Plato. Specifically, let us approach a loose ending by sticking our heads into Aristophanes' Clouds. The play opens with the laments of Strepsiades, an "old bumpkin" whose son, Phidippides, has a passion for horse racing (I998, II). That passion, Strepsiades gripes, has "infected [his] estate with the galloping trots" ( ${ }_{5}$ ), leaving him "eaten alive by . . . bills and stable fees and debts" (II). Desperate, Strepsiades seeks to enroll his son in the "Thinkery" of Socrates. Socrates is here depicted as an inveterate "archsophist" (Henderson 1998, 4) whose school is watched over by a chorus of apparently irreverent muses: the clouds (11. 33- $\left.{ }^{-} 34\right)$. At the Thinkery, Strepsiades expects his son will receive a newfangled education allowing him to, à la Protagoras, make the weaker argument the stronger and thus to talk Strepsiades' creditors out of collecting (11. 94-99). Phidippides refuses, however, so dad enrolls instead. Socrates, who is gluing shoes on the feet of a flea when Strepsiades arrives (11. I49-52), attempts to teach his new student all manner of abstruse knowledge. Strepsiades seems an inept pupil, however: he is forgetful and distracted, tends to utter non sequiturs, and forces Socrates' esoteric teachings into economic contexts. When Socrates asks whether he would prefer to learn "measures, or rhythms, or words" (9I), 
for instance, Strepsiades replies, "I'll take the measures: the other day a corn dealer shorted me two quarts" (9I). After using sophistic logic to take his cloak and turn him into an atheist, Socrates eventually expels the hopelessly exasperating Strepsiades, who cannot seem to retain what he's supposed to have learned about grammar and declension (11. 787-90) — though he does display a momentary knack for dodging lawsuits (11. 769-73).

But Strepsiades subsequently convinces Phidippides to enroll in the Thinkery instead and persuades Socrates to admit his son (11. 866-87). A contest between personified versions of conservative Stronger Argument and fashionable Weaker Argument ends with Stronger defeated, and so Strepsiades leaves his son in Weaker's pedagogical care (IIO5-IO). When Phidippides returns from his studies, he provides his father with some newly strengthened weaker arguments he can use against the family's creditors (II70-I213). Strepsiades manages to run off two creditors-whether he "persuades" them seems doubtful - by deploying wildly incoherent and wayward reiterations of Socrates' and his son's arguments. He drives the first away, for instance, by returning to Socrates' lessons on the declension of nouns, claiming he "wouldn't repay a single penny to anyone who calls a morté a mortar" (I75). After that, however, the scheme backfires, with Phidippides making and acting on arguments in favor of children beating their parents (11. I332-I475). A scarified Strepsiades heads to the Thinkery and, in an act of destruction that ends the play, sets it on fire. As Socrates and his pupils suffocate and burn, Strepsiades justifies his actions, claiming, "They've got it coming many times over, but most of all for wronging the gods" (209).

As Ian C. Storey points out, Clouds is something of an oddity among Aristophanes' works. Its “down' ending” stands in contrast to his other plays, which usually wrap up with "general rejoicing" (I998a, xxxi). Strepsiades himself is also an outlier: in some ways, he does fit the mold of Aristophanes' typical "comic hero, the old countryman who achieves his great idea and comes out on top" (Storey I998b, 3). But, pointing to the scene in which Socrates attempts and apparently fails to teach Strepsiades, Storey notes that

the scene depends on stretching the spectator's reactions in two opposite directions: he wants to be a sophos like Socrates, for (unlike Strepsiades) he knows about measures and rhythms, and at the same time wants to see the sophos taken down a rung or two. We admire Strepsiades' low cunning and desire not to pay his debts, but at the same time we wince at his essential dishonesty and 
insistence at learning ... [Weaker] Argument. It can be observed that the "great idea" is undone at the end, that ... the play ends with destruction rather than jubilation and reconciliation. (1998b, 3-4)

He chalks this up to the fact that Clouds itself was a loser: after it came in third and last at the Dionysia of $423 \mathrm{BCE}$, Aristophanes revised it, mocking his tasteless spectators in an updated parabasis and-according to Storey's speculations-giving the play a darker ending (I998b, 7). In other words, Strepsiades is not necessarily, unlike some of Aristophanes' other "comic hero[es]," a common-sense alazon who gets the goat of a highfalutin eiron. He has his revenge on Socrates, but does not seem to have learned anything. Is his credibility, not to mention the credibility of the gods and/or Stronger Argument, purified in the flames of the burning Thinkery? An open question.

Given the account(ing) of irony I have pursued, perhaps Strepsiades is neither alazon nor eiron. Perhaps his role is-if I may say so-irony itself: He gets the first word in the play, interrupting all the other characters before they can begin to speak. He learns Socrates' lessons but fragments them in wildly irrational ways that shatter Socrates' educational and rhetorical protocols-ways that, to return to Ronell (2002), "give a sound beating to a language that closes in on itself" ( $\left.{ }_{5} 6\right)$. And in the end, the beaten and broken rube suddenly enacts the play's final act of destruction, burning the house of thought and its questionable inhabitants to the ground. Irony proves uncontrollable, abusing its Socratic master rather than getting used in that master's service. And so the unfigurable student gets the last word, which might be serious and might be a laugh, as well.

If, as rhetoricians, we were to imagine ourselves in the place of an Aristophanic Socrates, laid low by a hapless pupil previously dismissed as stupid, what (if anything) might we learn from irony's violence? Perhaps we should have attuned ourselves to it earlier. Perhaps Socrates would have succeeded with Strepsiades if he had been more considerate of the latter's backwoods speechifying rather than proclaiming, "To hell and be damned with you, you oblivious, moronic old coot!" (Aristophanes 1998, II5), if he had accepted the purported moron's responses as inventive interruptions, as openings for further response rather than aberrations in need of foreclosure. (After all, in other iterations of Socrates' story, it is precisely his unwillingness or inability to respond in the proper key that gets him killed.) Perhaps he could have even made room for this intractable idiot alongside the Thinkery's more facile pupils, opened a space for disorder-a topos for an atopos student-and thus saved the rest from going up in smoke along 
with their teacher. At the very least, listening for Strepsiades might have allowed a cannier Socrates to hear his destruction coming, leaving time to clear everyone out before the Thinkery burned down.

Or perhaps we always expect the unexpected too late; perhaps irony's unmasterable disaster is already "here. Where? There" (Derrida I988, 2I). Perhaps the most Socrates could have done was take action in the wake of a disaster that is "always already past" (Blanchot 1995, I): following the lead of the historical Socrates' accusers, he could have organized his surviving students and marched over to Strepsiades' door, demanded recompense and declared himself Strepsiades' new creditor or roasted Strepsiades to even the score.

In short, it may be that irony's arrival never gives us the chance to be a good host, to extend hospitality. It renders us, rather, a pedagogical hostage, stuck following after it rather than leading it or using it to lead-thus interrupting one etymological sense of "pedagogue," the one who leads ("agogos") the child ("pais"). In terms of pedagogical authority, then, what I am after is a "Socratic irony" that is not used by a masterful Socratic figure to lead students into orderly anamnesis and a deferral of deliberative authority to the teacher, but that disorders and deauthorizes "teacher" and "student" alike. It is, then, a linguistic violence to be weathered by us all even as it leads us to question the limits of such categories as "us" and "all."

All this may seem to have come entirely unglued from the pedagogical exigencies faced by twenty-first-century rhetoric teachers, so let me tie it to something more apparently concrete. In Teaching Community, writer and educator bell hooks (2003) recounts the following:

When the tragic events of $9 / \mathrm{II}$ occurred it was as though, in just a few moments in time, all our work to end domination in all its forms, all our pedagogies of hope, were rendered meaningless as much of the American public ... responded with an outpouring of ... patriarchal rage against terrorists defined as dark-skinned others. . . Even though I could walk to the sites of the $9 /$ II tragedy, I was not able to speak about these events for some time because I had come face-to-face with the limits of what I know. ... What I knew, the limits of my knowing, was defined by information in alternative mass media and by the boundaries of what I experienced, of all that I witnessed. That's all I could account for. Anything more would have been interpretations of interpretations offered me by a media whose agenda I hold suspect. (9-IO) 
Though hooks is specifically critiquing the rush to craft a comprehensible, reactionary narrative in the wake of $9 / \mathrm{II}$, I would like to trace out some broader implications in her narrative. The drive to fight fire with fire, whether in the interpretations hooks describes or in my hypothetical continuations of Clouds narrative, is a powerful one. It is in many ways an understandable response to events that shatter the limits of understanding: a refusal to admit and dwell with the fact that one has "come face-to-face with the limits" of knowledge, with a disaster we cannot simply experience or coherently account for. And it is here that I wonder about the interruptive, humbling, humiliating possibilities of a Socratic irony that would not seek to dissemble, to play on "unknown knowns" and "unknown unknowns" in order to justify the authority of patriarchal figures and render students and the rest of the demos ignorant of or unable to take responsibility for the deliberative response called for in the wake of irony's disasters. And this is not just about such obviously horrifying events as $9 / \mathrm{II}$ or the many other devastating historical events that defy attempts to speak of, write about, or represent them. It is also, I would argue, about the hundreds of moments that test the limits of us, of students, and of "our" languages every day, even when they mercifully do not involve arsonists. Irony might arrive as a grammar "error" in a student paper that if responded to and not simply struck out reveals rhetorical possibilities we had yet to consider ( $\mathrm{Lu} \mathrm{1994).}$ It might arrive as an interruptive comment in a class discussion that disfigures our conceptions of students, ourselves, and educational decorum, but if left to ferment rather than being ejected from the realm of what is allowed could generate a moment of pedagogical hospitality - a welcoming of the Other's expression that "means: to be taught" (Levinas 1969, 5I). Perhaps.

\section{Department of English Middle Tennessee State University}

\section{NOTES}

For their generous and incisive feedback on innumerable drafts of this piece, I am deeply grateful to Diane Davis, Kendall Gerdes, and Steven LeMieux. Any worthwhile utterance printed in the preceding pages is inextricably indebted to Steven's and Kendall's patience and intellect. Thanks also to the anonymous reviewers at Philosophy and Rhetoric for their insightful suggestions.

I. Postioning Socrates among the ranks of "rhetoric teachers" may strike readers as a questionable move. For the moment, I will just note that a number of texts have explored 


\section{disfiguring socratic irony}

Socrates' sophistic tendencies and rhetorical impulses; see, for example, Colebrook 2004, 30, Henderson I998, 4, and Kennedy 1994, 20.

2. In addition to Libanius's complaints, consider the numerous satiric depictions of Roman teachers of rhetoric (Lucian 1925; Petronius 1997).

3. To both avoid and risk falling into my own Platonism, let me pause to unpack my deployment of "Platonic" as an adjective that might itself be read as essentializing. "What is $x$ ?" questions "are" Platonic only insofar as Plato "is," in our historical moment, generally interpreted as a philosopher who saw the essence or nature of an idea or concept as metaphysical and not delimited by historical, rhetorical, and/or hermeneutic variables and variations. Such a question is not essentially Platonic given that, at some point, Plato's dialogues might be interpreted-however oddly — as nonessentialist and not purely metaphysical. As I preface this article's encounter with the Gorgias, then, I do not mean to suggest that Socrates (Plato's or otherwise) is an essentialist or idealist. I have in mind, rather, extensive hermeneutic traditions that read Plato's Socrates as such-traditions whose interpretive certitudes I hope to unsettle.

4. In some ways, my concerns about irony resonate with Christopher J. Gilbert's (2013) concerns about satire. "Satire," Gilbert states, "accommodates such a vast array of traits that I hesitate to redefine what it is, never mind what it does" (284). However, while Gilbert works to recover the "figure" of the "satyric" "in the interest of political humor," I remain skeptical of anyone's ability to simply take up irony - as "figure" or otherwisefor political ends, though irony can certainly have consequences for politics (299).

5. The sort of ironic undecidability that I am tracking has been addressed at length by Blanchot, Ronell, and-perhaps most recognizably-Derrida. This article's treatment might thus seem like a retread, redundant. My motive for retracing it here is to connect it with rhetoric pedagogy. Even among rhetoricians with a taste for Derridean undecidability, that undecidability is often positioned as part and parcel of rhetorical theory, a conceptual or critical concern that unfolds in relative isolation from rhetoric's pedagogical scene (see the anonymous colleague referenced in Walker 20II, I4-I6). Though I do not wish to suggest there is a positive relationship between rhetoric pedagogy and ironic undecidability, I do believe that they have things to say to each other and that they are perhaps saying things to each other already.

6. See David Wolfsdorf's consideration of "Plato's intentions" as he works to defineand basically cancel out- "Socratic irony" (2007, I8I).

7. See note 3 .

8. Given my concern with irony, I should note that Richard Rorty (I989) categorizes Foucault as an "ironist"-more precisely, "an ironist who is unwilling to be a liberal" (6r). Rorty also includes Derrida, Heidegger, and Nietzsche in this category, which he aligns with the "private" side of a "public"/"private" binary that explicitly undergirds Contingency, Irony, and Solidarity. For Derrida's response to Rorty's private/public distinction, see "Remarks on Deconstruction and Pragmatism" (I996, 80-8I). Given my article's 
place within what might be called a "tradition" of Derridean aberrations, I will not have much more to say about Rorty's work on irony, though it is in many ways valuable (for more on Rorty's relation to irony, see Stroud 2014, 306-9).

9. See the totalizing, unity-driven Platonism Paul Ramsey (2009) maps onto "modern conservatives' curricular agenda" (573).

Io. I borrow the terms "alazon" and "eiron" from de Man, who in term borrowed them from Greek comedy. Here is de Man: "It helps a little to think of it [i.e., irony] in terms of the ironic man, in terms of the traditional opposition between eiron and alazon, as they appear in Greek or Hellenic comedy, the smart guy and the dumb guy. Most discourses about irony are set up that way, and this one will also be set up that way. You must then keep in mind that the smart guy, who is by necessity the speaker, always turns out to be the dumb guy, and that he's always being set up by the person he thinks of as being the dumb guy, the alazon" (1996, 165).

II. In the context in which Plato's using it, "eirōneuēe" is closer to "dissembling" or "feigning ignorance" than the more recent sense of "not saying what you mean," though it is not entirely distinct from the latter. For all the glosses of Greek terms included in this article, I am significantly indebted to the patience and know-how of Jeffrey Walker.

I2. That the authorship of this letter remains uncertain only further multiplies the possibilities outlined here.

13. For a different take on Latour's broader corpus, and one that might justly call some of my characterizations of his work into question, see Santos 2015. Let me reiterate that I am particularly focused on Latour's reading of the Gorgias and that some of his other writings share points of overlap with my own claims.

I4. Latour quotes from Robin Waterfield's (1994) translation of the Gorgias. Waterfield notes that the "experts" Socrates is speaking of are likely the Pythagoreans and some preSocratics, whom Waterfield claims "perceived the universe as in some sense an ordered whole" (160). Zeyl, meanwhile, renders the same passage (507e-508a) as follows: "Yes, Callicles, wise men claim that partnership and friendship, orderliness, self-control, and justice hold together heaven and earth, and gods and men, and that is why they call the universe a world order, my friend, and not an undisciplined world-disorder" (Plato I987, 88). Given Latour's championing of this passage, Waterfield's "ordered whole" certainly has a nicer ring than Zeyl's ominously italicized "world order."

I5. Latour's interest in "conditions of felicity" arguably precludes Derrida's (I988) interest in "opportunit[ies] to transform infelicity into delight" (72, emphasis mine).

\section{WORKS CITED}

Aristophanes. 1998. Clouds. In Clouds, Wasps, Peace. Trans. Jeffrey Henderson. Cambridge, MA: Harvard University Press.

Blanchot, Maurice. 1995. The Writing of the Disaster. Trans. Ann Smock. Lincoln: University of Nebraska Press. 
Chinatown. 1999. DVD. Hollywood, CA: Paramount.

Colebrook, Claire. 2004. Irony. London: Routledge.

Cribiore, Raffaella. 20oI. Gymnastics of the Mind: Greek Education in Hellenistic and Roman Egypt. Princeton, NJ: Princeton University Press.

- 2007. The School of Libanius in Late Antique Antioch. Princeton, NJ: Princeton University Press.

Crowley, Sharon. 1998. Composition in the University: Historical and Polemical Essays. Pittsburgh, PA: University of Pittsburgh Press.

de Man, Paul. 1996. “The Concept of Irony.” In Aesthetic Ideology, ed. Andrzej Warminski, I63-84. Minneapolis: University of Minnesota Press.

Derrida, Jacques. 1988. Limited Inc. Evanston, IL: Northwestern University Press.

- 1996. "Remarks on Deconstruction and Pragmatism." In Deconstruction and Pragmatism, ed. Chantal Mouffe, trans. Simon Critchley, 79-9o. London: Routledge.

Foucault, Michel. 1982. "The Discourse on Language." Trans. Rupert Swyer. In The Archaeology of Knowledge, 215-38. New York: Vintage.

Gilbert, Christopher J. 2013. "Toward the Satyric." Philosophy and Rhetoric 46 (3): 280-305.

Gorgias. "Encomium of Helen." In On Rhetoric: A Theory of Civic Discourse, by Aristotle, trans. George Kennedy, 25I-56. New York: Oxford University Press.

Hauser, Gerard A. 2004. "Teaching Rhetoric; or, Why Rhetoric Isn't Just Another Kind of Philosophy or Literary Criticism." Rhetoric Society Quarterly 34 (3): 39-53.

Henderson, Jeffrey. 1998. Introductory note to Clouds, by Aristophanes, 3-7. Cambridge, MA: Harvard University Press.

hooks, bell. 2003. Teaching Community: A Pedagogy of Hope. New York: Routledge.

Kennedy, George A. 1994. A New History of Classical Rhetoric. Princeton, NJ: Princeton University Press.

Kierkegaard, Søren. 1989. The Concept of Irony with Continual Reference to Socrates. Ed. and Trans. Howard V. Hong and Edna H. Hong. Princeton, NJ: Princeton University Press.

Latour, Bruno. 1997. “Socrates' and Callicles'Settlement; or, The Invention of the Impossible Body Politic." Configurations 5 (2): 187-240.

Levinas, Emmanuel. 1969. Totality and Infinity: An Essay on Exteriority. Trans. Alphonso Lingis. Pittsburgh, PA: Duquesne University Press.

Lu, Min-Zhan. 1994. "Professing Multiculturalism: The Politics of Style in the Contact Zone." College Composition and Communication 45 (4): 442-58.

Lucian. 1925. "A Professor of Public Speaking." Trans.A.M.Harmon.London: Heinemann.

Mirhady, David C., and Yun Lee Too, trans. 2000. Isocrates. Vol. I. Austin: University of Texas Press.

Petronius, Gauis. 1997. The Satyricon. Trans. P. G. Walsh. Oxford: Oxford University Press.

Plato. 1925. Lysis. In Lysis, Symposium, Gorgias. Trans. W. R. M. Lamb. Cambridge, MA: Harvard University Press.

- 1973. Seventh Letter. In Phaedrus and Letters, vols. 7 and 8, ed. and trans. Walter Hamilton, III-I50. London: Penguin.

—. 1987. Gorgias. Trans. Donald J. Zeyl. Indianapolis, IN: Hackett.

- I994. Gorgias. Trans. Robin Waterfield. Oxford: Oxford University Press. 


\section{ERIC DETWEILER}

1995. Phaedrus. Trans. Alexander Nehamas and Paul Woodruff. Indianapolis, IN: Hackett.

Ramsey, Paul. 2009. "Plato and the Modern American 'Right': Agendas, Assumptions, and the Culture of Fear." Educational Studies 45 (6): 572-88.

Ronell, Avital. 2002. Stupidity. Urbana: University of Illinois Press.

- 2012. Loser Sons: Politics and Authority. Urbana: University of Illinois Press.

Rorty, Richard. 1989. Contingency, Irony, and Solidarity. Cambridge: Cambridge University Press.

Santos, Marc C. 2015. "Uncrossing God: How Levinas's Ethics Might Contribute to Latour's Politics." Philosophy and Rhetoric 48 (3):313-36.

Storey, Ian C. I998a. General introduction to Clouds, Wasps, Birds, by Aristophanes, vii-xxxv. Indianapolis, IN: Hackett.

- I998b. Introduction to Clouds. In Clouds, Wasps, Birds, by Aristophanes, 2-7. Indianapolis, IN: Hackett.

Stroud, Scott R. 20I4. "Comprehensive Rhetorical Pluralism and the Demands of Democratic Discourse: Partisan Perfect Reasoning, Pragmatism, and the Freeing Solvent of Jaina Logic." Philosophy and Rhetoric 47 (3): 297-322.

Too, Yun Lee. 200o. The Pedagogical Contract: The Economies of Teaching and Learning in the Ancient World. Ann Arbor: University of Michigan Press.

Vasiliou, Iakovos. 2002. "Socrates' Reverse Irony." Classical Quarterly 52 (I): 220-30.

Walker, Jeffrey. 20Ir. The Genuine Teachers of This Art: Rhetorical Education in Antiquity. Columbia: University of South Carolina Press.

Wolfsdorf, David. 2007. "The Irony of Socrates." Journal of Aesthetics and Art Criticism $65(2): 175^{-87}$.

Zeyl, Donald J. I987. Introduction to Gorgias, by Plato, ix-xv. Indianapolis, IN: Hackett. 